\title{
Effect of purmorphamine on the mRNA expression of Sonic Hedgehog signaling downstream molecules in ovine embryo
}

\author{
Parisa Nadri, Saeid Ansari-Mahyari, and Azadeh Zahmatkesh \\ Department of Animal Science, College of Agriculture, Isfahan University of Technology, \\ Isfahan 8415683111, Iran
}

Correspondence to: Parisa Nadri (parisa.nadri@yahoo.com) and Saeid Ansari Mahyari (s.ansari@cc.iut.ac.ir)

Received: 9 December 2015 - Revised: 4 April 2016 - Accepted: 6 April 2016 - Published: 15 April 2016

\begin{abstract}
Sonic Hedgehog (SHH) is a signaling pathway mediated through a receptor system which seems to have effects on oocyte maturation and embryonic development. Purmorphamine is an SHH agonist that performs a crucial role in the regulation of the activity of SHH receptors and downstream transcription factors. The aim of this study was to analyze the effect of purmorphamine on the mRNA expression of SHH signaling downstream molecules (Patched1, Glioma-Associated Oncogene1, Smoothened, Histone Deacetylase1, Histone Deacetylase 2 and Histone Deacetylase3) in ovine two-cell embryo. Ovaries were obtained from a slaughterhouse, and cumulus-oocyte complexes were aspirated and cultured in maturation media containing 0,250 or $500 \mathrm{ng} \mathrm{mL}-1$ purmorphamine. Then, oocytes were fertilized and cultured in a CR1 culture medium and after $24 \mathrm{~h}$, two-cell embryos were collected for RNA extraction. Gene expression was evaluated by real-time polymerase chain reaction (PCR). Results indicated that in $250 \mathrm{ng} \mathrm{mL}^{-1}$ purmorphamine, Smo, Ptchl and Hdac3 expression reduced, Hdacl expression increased, and Glil and Hdac2 expression levels did not change. In $500 \mathrm{ng} \mathrm{mL}^{-1}$ purmorphamine, Glil and Smo transcripts increased, while Ptch1, Hdac2 and Hdac3 transcripts decreased. Regarding to the presence of SHH signaling molecules in two-cell embryos and their response to purmorphamine, it can be suggested that SHH signaling is probably active before embryonic genome activation in ovine embryos.
\end{abstract}

\section{Introduction}

It is well known that embryos derived from in vivo matured oocytes are superior to embryos derived from in vitro matured oocytes in terms of quantity and quality, but studies have shown that in vitro maturation of oocytes and production of embryos is possible (Crozet et al., 1987). In vivo maturation of oocytes is influenced by different environmental factors, such as steroids and growth factors (Driancourt and Thuel, 1998). Hence, in order to enhance the environmental conditions, researchers have been adding these factors to the oocyte maturation medium, which has led to many changes in the process of oocyte maturation and the subsequent embryo production (Ikeda et al., 2000). Sonic Hedgehog (SHH) is one of these factors that seems to have effects on the oocyte maturation, cell proliferation and embryonic development in human and animal species (Nguyen et al., 2011). The Hedge- hog $(\mathrm{HH})$ protein is a paracrine factor which enhances cell proliferation and differentiation in many cell types (Elia et al., 2007). Its role in embryo development has attracted considerable attention over the past decade (Pangas, 2007). Its signaling pathway is mediated through a cell surface receptor system consisting of two proteins; the receptor Patched 1 (Ptchl) and its coreceptor Smoothened (Smo) (Hooper and Scott, 2005). In the absence of SHH, Smo is inhibited by Ptchl receptors, and this consequently leads to the inactivation of Glioma-Associated Oncogene 1 (Glil) transcription factor, while in the presence of SHH, Smo is released and then the Glil protein is translocated to the nucleus, which increases transcription of genes (Ruiz i Altaba et al., 2002; Hooper and Scott, 2005) such as Histone Deacetylase 1 (Hdacl) in the nucleus (Canettieri et al., 2010). Hdac1, 2 and 3 enzymes belong to the $H d a c$ family and are encoded by the human Hdacl, 2 and 3 genes, respectively. These proteins 
have notable roles on epigenetic programming, regulation of gene expression and transcription, cell cycle progressing, and the development of embryos (Mehnert and Kelly, 2007). SHH has been shown to change the Hdac gene expression pattern and activity in SHH-induced medulloblastoma (Lee et al., 2006). There is no report on the effect of HH signaling on epigenetic changes and Hdac expression during minor zygote genome activation in ovine two-cell embryos.

$\mathrm{HH}$ signaling molecules exist in the murine (Wijgerde et al., 2005; Russell et al., 2007; Ren et al., 2009) and bovine (Spicer et al., 2009) reproductive systems. They are proposed to function as paracrine factors to promote cell proliferation and steroid hormone production. On the other hand, HH signaling, particularly Indian Hedgehog (IHH), has been shown to promote the preimplantation development of embryos in mice (Lee et al., 2006).

Porcine studies demonstrated that $\mathrm{HH}$ signaling molecules including Ptch1, Smo and Gli1 are present in the ovaries, oocytes and parthenogenetic embryos at different stages. Inclusion of exogenous SHH in the in vitro maturation (IVM) or in vitro culture (IVC) media enhanced oocyte maturation and development of parthenogenetic embryos (Nguyen et al., 2009, 2010).

The HH molecular signaling pathway has been shown to be affected by a small molecule named purmorphamine. Purmorphamine is an SHH signaling activating agonist that has been developed by Wu et al. (2002). This small molecule performs a crucial role in the regulation of the activity of Smo and Ptchl receptors and Glil transcription factor (Nguyen et al., 2011). Due to the positive effective of SHH factors on porcine oocyte maturation and embryo development (Nguyen et al., 2011), the idea has emerged that purmorphamine may also have the same positive effect. Therefore, the aim of this study was to investigate the effect of this factor on the expression of Ptchl, Glil, Smo, and the Hdacl, 2 and 3 genes in ovine two-cell embryos derived from in vitro fertilization (IVF) experiments.

\section{Materials and methods}

All chemicals and media were obtained from Sigma-Aldrich Co. (St. Louis, MO, USA), unless otherwise specified. All experiment procedures were approved by the review committee for the use of animal samples by the Stem Cell Technology Research Center (Tehran, Iran), and animal experimentations including ovine slaughter and ovarian sample collection were in agreement with the ethical commission.

\subsection{Oocyte collection and IVM}

Ovine ovaries were obtained from an industrial abattoir and transported to the laboratory at $35^{\circ} \mathrm{C}$ in physiological saline within $2 \mathrm{~h}$. Cumulus oocyte-complexes (COCs) were aspirated from medium-sized follicles $(3-7 \mathrm{~mm}$ in diameter) with an 18 gauge needle. Then COCs were washed in
HEPES-TCM 199 (31100-027; Gibco, Invitrogen, Germany) supplemented with $10 \%$ fetal bovine serum (FBS). Only COCs with at least two layers of cumulus cells and a homogeneous ooplasm were selected under a microscope and then washed three times in maturation medium. Then, 10 to 12 COCs were randomly allocated to a $50 \mu \mathrm{L}$ droplet of TCM 199 maturation medium supplemented with $10 \%$ FBS, $5 \mu \mathrm{g} \mathrm{mL}^{-1}$ luteinizing hormone, $5 \mu \mathrm{g} \mathrm{mL}^{-1}$ follicle stimulating hormone, $1 \mu \mathrm{g} \mathrm{mL}^{-1}$ estradiol and different concentrations of purmorphamine ( 250 or $500 \mathrm{ng} \mathrm{mL}^{-1}$ purmorphamine (Santa Cruz Inc., California, USA), or without purmorphamine (control group) (Thompson et al., 1995). Then they were cultured in an incubator containing $5 \% \mathrm{CO}_{2}$ for $22 \mathrm{~h}$ at $39^{\circ} \mathrm{C}$. The purmorphamine concentrations were selected according to a previous study (Nguyen et al., 2009, 2010).

\subsection{Sperm preparation and IVF}

After IVM, the COCs were washed once in the fertilization medium (Ham's F-10), and 30 COCs were then transferred to individual $100 \mu \mathrm{l}$ droplets of IVF medium. Sperm preparation was performed by the swimming up procedure, and motile sperms were added to fertilization droplets at the final concentration of $10^{6}$ sperms $\mathrm{mL}^{-1}$. Then plates were incubated in a $39^{\circ} \mathrm{C}$ humidified atmosphere with $5 \% \mathrm{CO}_{2}$ and $5 \% \mathrm{O}_{2}$ for $18 \mathrm{~h}$. After IVF, presumptive zygotes were denuded from surrounding cumulus cells by vortexing for 5 min in H-TCM10 medium supplemented with $10 \%$ FBS and $0.1 \%$ hyaluronidase. Then zygotes were transferred to CR1aa medium droplets and incubated in a humidified atmosphere $\left(5 \% \mathrm{CO}_{2}\right.$ and $\left.5 \% \mathrm{O}_{2}\right)$ at $39^{\circ} \mathrm{C}$ for $24 \mathrm{~h}$. Thereafter, two-cell embryos were collected from different treatment groups (Tervit et al., 1972).

\subsection{RNA extraction and simultaneous cDNA synthesis}

To analyze the effect of purmorphamine on the expression of Ptchl, Smo, Glil, and Hdacl, 2 and 3 genes in ovine two-cell embryos, three biological replicates for each sample, containing 10 denuded matured oocytes, were considered for RNA extraction. The IVF embryos were washed in phosphate buffered saline and transferred into Eppendorf tubes containing a $1.5 \mathrm{~mL}$ cellular lysis buffer (Zuccotti et al., 2002). Total RNA from embryos was extracted by using a Qiazol reagent (Qiagen). Complementary DNA was synthesized by a First Strand cDNA Synthesis Kit (Fermentas, Germany) according to the company's instructions. Concisely, $3 \mu \mathrm{g} \mathrm{mL}^{-1}$ random hexamer and $5 \mu \mathrm{L}$ nuclease-free water were added to the tubes. Then tubes were placed in a thermocycler (Bio-Rad, Hercules, CA, USA) for $5 \mathrm{~min}$ at $75^{\circ} \mathrm{C}$. Then tubes were placed on ice and $5 \mu \mathrm{L}$ reverse transcription buffer $5 \mathrm{X}, \mu \mathrm{L}$ RT enzyme ( $\left.200 \mathrm{u} \mu \mathrm{L}^{-1}\right), 3 \mu \mathrm{L}$ dNTP $(10 \mathrm{mM})$ and $0.25 \mu \mathrm{L}$ RNase inhibitor $\left(20 \mathrm{u} \mu \mathrm{L}^{-1}\right)$ were added to a $10 \mu \mathrm{L}$ total reaction volume. The program for reverse tran- 
Table 1. Primer sequences, product size and accession numbers.

\begin{tabular}{|c|c|c|c|}
\hline Gene name & Primer sequences & Product size $(\mathrm{bp})$ & Accession numbers \\
\hline Sheep Gli1 & F: CAC ATC AAC AGT GAG CAC ATC & 186 & XM_004006540.1 \\
\hline & R: TTC CAG GCG TGA GTA TGA & & \\
\hline Sheep Smo & F: GGG CTA TAA GAA CTA CCGAT & 135 & XM_004008282.1 \\
\hline & R: GGT GGT TGC TCT TGA TG & & \\
\hline Sheep Ptchl & $\begin{array}{l}\text { F: GAC TGG CTC CAA GGA CTT C } \\
\text { R: GTT TGT ACC AGG AGT TTG TA }\end{array}$ & 122 & XM_004004089.1 \\
\hline Sheep Hdacl & $\begin{array}{l}\text { F: GAC AAA CGC ATC TC AT } \\
\text { R:TTG GCT TTC TTG AAG TT }\end{array}$ & 119 & XM_004005023.1 \\
\hline Sheep Hdac2 & $\begin{array}{l}\text { F: ATG GAA AAG ATA AAA CAG } \\
\text { R: CTA TTC GTT TGT GTG ATG CT }\end{array}$ & 169 & XM_004011189.1 \\
\hline Sheep Hdac3 & $\begin{array}{l}\text { F: ACA AAT ACG GAA ACT T } \\
\text { R: GAA AAG GTGCTT GTA ACT C }\end{array}$ & 131 & XM_00400891.1 \\
\hline Sheep $G A P D H$ & $\begin{array}{l}\text { F: AGT GTC GTT GAA GTC } \\
\text { R: GAA ACC TGC CAA GTA TGAT }\end{array}$ & 121 & XM_001190390.1 \\
\hline
\end{tabular}

scription was as follows: $25^{\circ} \mathrm{C}$ for $10 \mathrm{~min}, 37^{\circ} \mathrm{C}$ for $15 \mathrm{~min}$, $42^{\circ} \mathrm{C}$ for $45 \mathrm{~min}$ and $72^{\circ} \mathrm{C}$ for $10 \mathrm{~min}$.

\subsection{PCR and real-time PCR}

To detect the expression of Ptch1, Smo, Glil, Hdacl, Hdac2 and Hdac 3 genes in ovine two-cell embryos, primers were designed by the Oligo 7 software. Primer sequences and their related information are shown in Table 1 . The polymerase chain reaction (PCR) condition for all genes is as follows: $95^{\circ} \mathrm{C}$ for $5 \mathrm{~min}, 35$ cycles of $95^{\circ} \mathrm{C}(20 \mathrm{~s}), 60^{\circ} \mathrm{C}(20 \mathrm{~s}), 72^{\circ} \mathrm{C}$ $(20 \mathrm{~s})$, and the final extension at $72^{\circ} \mathrm{C}$ for $10 \mathrm{~min}$. GAPDH was used as a housekeeping gene and accuracy control of the reverse transcription process. PCR products were visualized in $2 \%$ tris-acetate-EDTA agarose gel after electrophoresis and staining in ethidium bromide. Quantitative real-time PCR was performed to analyze the effect of purmorphamine on the expression of Ptch1, Smo, Glil, Hdacl, Hdac2 and Hdac3 genes in ovine two-cell embryos by using a RotorGene Q instrument (Qiagen, Hilden, Germany). Real-time PCR reactions took place in a total volume of $13 \mu \mathrm{L}$, consisting of $6.5 \mu \mathrm{L}$ SYBR Green PCR master mix (Takara, Japan), $4.5 \mu \mathrm{L}$ distilled water, $1 \mu \mathrm{L}$ of forward and reverse primers $\left(10 \mathrm{pmol} \mu \mathrm{L}^{-1}\right)$ and $1 \mu \mathrm{L}$ cDNA. The amplification program was as follows: $3 \mathrm{~min}$ at $95^{\circ} \mathrm{C}$ for enzyme activation and 40 cycles of $5 \mathrm{~s}$ at $95^{\circ} \mathrm{C}, 15 \mathrm{~s}$ at $60^{\circ} \mathrm{C}$ and $10 \mathrm{~s}$ at $72^{\circ} \mathrm{C}$. Finally, a melting step was carried out for confirmation of the specificity of amplification. Ovine GAPDH primers were used as the external control (Livak and Schmittgen, 2001), and the mRNA level of each sample was normalized to that of GAPDH. All primer sequences of the experiment are shown in Table 1.

\subsection{Statistical analysis}

The analysis of gene expression was performed using the REST-2009 software. Relative gene expression levels of dif-

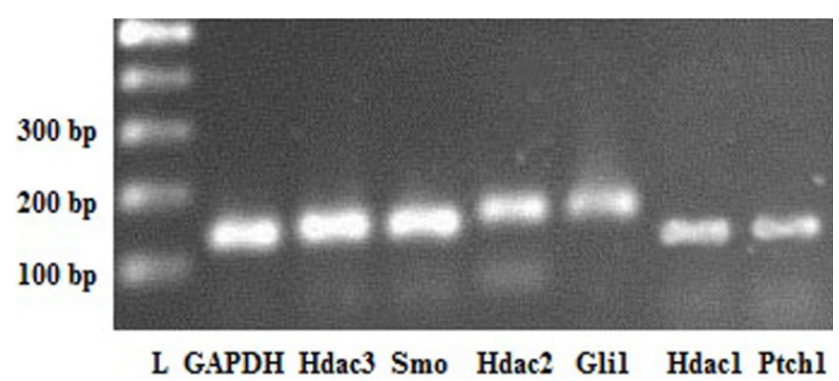

Figure 1. PCR result of ovine two-cell embryo. A 100 bp DNA ladder (L) was used as a size marker.

ferent genes among the groups were statistically analyzed based on one-way analysis of variance (ANOVA) followed by Tukey's pairwise comparisons, and then significant differences between the treatments were examined at $p<0.05$.

\section{Results}

Success in PCR amplifications demonstrates that Ptchl, Smo, Glil, Hdacl, Hdac2 and Hdac3 transcripts are present in ovine two-cell embryos (Fig. 1). The expression levels of Glil, Ptchl and Smo genes in two-cell embryos in different treatment groups of 250 and $500 \mathrm{ng} \mathrm{mL}^{-1}$ purmorphamine and control (without purmorphamine) are shown in Fig. 2. According to our data, at $250 \mathrm{ng} \mathrm{mL}^{-1}$ purmorphamine, no significant difference was observed in the expression of the Glil gene compared to the control. Increasing the concentration of purmorphamine to $500 \mathrm{ng} \mathrm{mL}^{-1}$ led to a significant increase in Glil gene expression compared with the control $(p<0.05)$. Treatment with 250 and $500 \mathrm{ng} \mathrm{mL}^{-1}$ purmorphamine significantly increased Smo expression compared with the control, although no significant difference was observed between the 250 and $500 \mathrm{ng} \mathrm{mL}^{-1}$ purmorphamine 


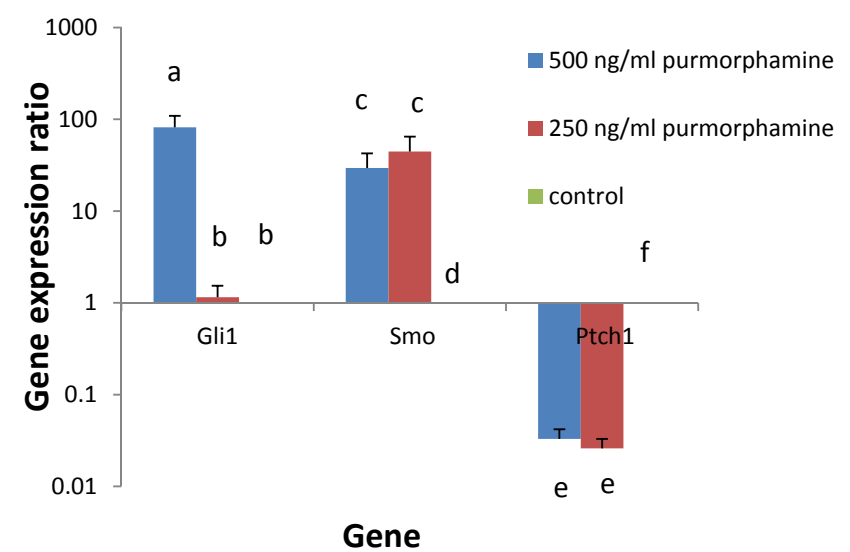

Figure 2. Gli1, Ptchl and Smo gene expression ratios in different purmorphamine treatments in ovine two-cell embryos. The number of transcripts in the control was set to 1 . Different letters in each gene indicate a significant difference $(p<0.05)$.

treatments. Ptchl transcripts significantly reduced in treated groups compared with the control, but no significant difference was observed between the two treatments.

Real-time data of Hdacl, Hdac2 and Hdac3 gene expression are shown in Fig. 3. Results show that the expression of $\mathrm{Hdacl}$ significantly increased in $250 \mathrm{ng} \mathrm{mL}^{-1}$ purmorphamine compared with the control. In contrast, raising the concentration to $500 \mathrm{ng} \mathrm{mL}^{-1}$ purmorphamine did not affect the $\mathrm{Hdacl}$ gene expression. No significant difference was found in $H d a c 2$ gene expression in $250 \mathrm{ng} \mathrm{mL}^{-1}$ purmorphamine, although increasing the concentration to $500 \mathrm{ng} \mathrm{mL}^{-1}$ significantly decreased the gene expression in comparison with the control group. Hdac3 transcripts showed a reduction in both purmorphamine treatments compared with the control, but no significant difference between the 250 and $500 \mathrm{ng} \mathrm{mL}^{-1}$ treatments was observed.

\section{Discussion}

HH signaling has been detected in murine (Wijgerde et al., 2005; Russell et al., 2007; Ren et al., 2009) and bovine ovaries (Spicer et al., 2009) in recent years. Specifically, HH downstream molecules, Ptch1 and Gli1, were primarily reported to be expressed in theca cells, whereas IHH, Desert Hedgehog (DHH) and SHH mRNAs were predominately detected in granulosa cells, with the function of stimulating cell proliferation in vitro (Wijgerde et al., 2005; Russell et al., 2007). Ren et al. (2009) reported that the activation of the $\mathrm{HH}$ signaling pathway alters theca cell development and prevents ovulation. It has been reported that SHH-related signaling molecules exist in porcine ovaries, and adding SHH to the IVM medium promotes the subsequent development of porcine parthenogenetic embryos (Neguen et al., 2009). In addition, IHH has been shown to play a crucial role in murine embryo implantation and during the preimplantation

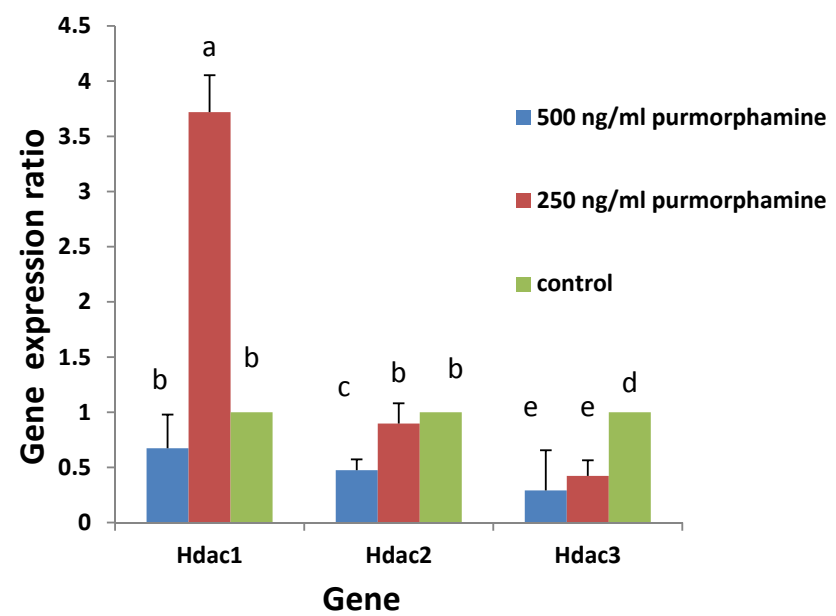

Figure 3. Hdacl, Hdac2 and Hdac3 gene expression ratios in different purmorphamine treatments in ovine two-cell embryos. The number of transcripts in the control was set to 1 . Different letters in each gene group indicate a significant difference $(p<0.05)$.

period (Lee et al., 2006; Matsumoto et al., 2002; Takamato et al., 2002). However, there are apparently no reports regarding the direct role of SHH in preimplantation embryo development. Neguen et al. (2009) reported that SHH and related signaling molecules (e.g., Ptchl, Smo and Glil), are expressed in porcine ovaries, specifically in the COCs. In the present study, we detected Ptchl, Smo, Glil, Hdacl, Hdac2 and $H d a c 3$ transcripts in ovine two-cell embryos, which indicates a possible role of these genes in ovine preimplantation development. Since embryonic genome activation (EGA) occurs at 8- to 16-cell stages in ovine embryos (Camous et al., 1986), the presence of these transcripts at the two-cell stage is most likely a maternal legacy.

It has been generally accepted that the expression of Ptchl, Smo and Glil genes is an indicator of $\mathrm{HH}$ signaling activation (Ingham et al., 2001). The presence of Ptchl, Smo and Glil transcripts at the ovine two-cell embryonic stage suggests that a similar SHH signaling pathway is needed for the progression of embryo development in sheep as in mice and pigs. $\mathrm{HH}$ signaling molecules are proposed to function as paracrine factors to promote cell proliferation and steroid hormone production (Russell et al., 2007; Spicer et al., 2009). Adding exogenous SHH to IVM or IVC media has been shown to enhance oocyte maturation and the development of parthenogenetic embryos (Nguyen et al., 2009, 2010). Based on these pieces of information, the expression of Glil, Smo and Ptchl genes in two-cell embryos may be a good parameter to evaluate developmental competence in ovine embryo in vitro production, which needs to be examined more closely in further studies. Additionally, based on real-time PCR analysis, we found that adding different concentrations of purmorphamine, an SHH agonist, to the IVM medium, alters the expression of SHH downstream transcripts in ovine twocell embryos. In $250 \mathrm{ng} \mathrm{mL}^{-1}$ purmorphamine, Smo, Ptchl 
and Hdac 3 expression was reduced, but Hdac 1 expression increased, while Gli1 and $\mathrm{Hdac} 2$ expression levels did not change. In $500 \mathrm{ng} \mathrm{mL}^{-1}$ purmorphamine, both Glil and Smo transcripts increased, while Ptchl, Hdac2 and Hdac3 transcripts showed a reduction. These changes in gene expression in in vitro treatment with an SHH agonist, shows a possible active SHH pathway in ovine two-cell embryos, as the expression of Ptch1, Smo and Glil is also expected by cells with a functional $\mathrm{HH}$ pathway. HH ligands have been demonstrated to be expressed in murine granulose cells (Russell et al., 2007) and porcine cumulus-oocyte complexes (Nguyen et al., 2009). Thus, it can be suggested that granulosa or cumulus SHH may act as a paracrine factor on oocytes during the maturation process, and the oocyte or the subsequent developing embryo may be potential targets of SHH signaling in ovine species.

According to a previous report (Canettieri et al., 2010), it seems that Glil activation leads to an increase in Hdac gene expression but results in a current study showed that changes in Glil transcription resulted in different expression profiles in Hdac genes. This indicates that there is probably a complicated process affecting $H d a c$ gene expression, and possibly purmorphamine could affect molecules other than Glil in the maturing oocytes, which results in different Hdac family expression patterns. It has been reported that $\mathrm{HH}$ signaling includes the activation of a group of transcription factors (Gli1, Gli2 and Gli3), which may act as either transcriptional activators or repressors (Ruiz i Altaba et al., 2002). Hence, a gene expression analysis of Gli2 and Gli3 would be helpful in understanding the underlying mechanism.

It seems that a decrease in Ptch 1 and an increase in Smo and Glil transcripts could be expected theoretically as a result of SHH signaling pathway activation by the SHH agonist, which is observed in the $500 \mathrm{ng} \mathrm{mL}^{-1}$ purmorphamine treatment. Whether these changes in SHH downstream molecules are associated with higher developmental competence or not, should be studied further.

Histone acetylation and deacetylation are catalyzed by multiple subsets of molecules and perform crucial roles in regulating eukaryotic gene expression. Histone deacetylases are a kind of enzyme whose function results in tight turns of DNA around the histones and DNA condensation, which is vitally important for switching off the expression of DNA (Stebbins-Boaz et al., 1996). There have been some reports on the gene expression of histone deacetylases in embryos of different species. A bovine study showed that the expression of the Hdacl gene is higher than that of the Hdac2 and Hdac3 genes in two-cell stage embryos (McGraw et al., 2003). There is no study on the effect of SHH or its agonists in an oocyte maturation medium on Hdac family gene expression, although it has been reported that adding Smoothened agonist (SAG), an SHH agonist, to the culture medium of cerebellar granule precursor (CGP) cells derived from medulloblastoma was accompanied by an increase in the expression and function of Hdacl, 2 and 3 genes (Lee et al., 2013). Our results demonstrated that although Hdacl, 2 and 3 genes are homologous, they show alternative patterns of expression in response to different purmorphamine treatments, which indicates a possible difference in their gene activation process and also their next functions.

As a conclusion, regarding the presence of SHH signaling molecules in ovine two-cell embryos and their alternative response to in vitro treatment with purmorphamine, it can be suggested that SHH signaling is probably active before EGA in ovine embryos. Further expression data on other molecules involved in SHH signaling and studying the viability and developmental competence of embryos at later preimplantation stages would be helpful in order to obtain comprehensive knowledge on the efficiency of using purmorphamine as a possible development-improving factor in culture media.

Author contributions. P. Nadri designed the experiments, carried them out and drafted the paper. S. Ansari-Mahyari supervised and designed the study. A. Zahmatkesh analyzed the data and prepared the manuscript with contributions from all coauthors.

Acknowledgements. The authors would like to acknowledge the authorities and staff of the Stem Cell Technology Research Center (Tehran, Iran) for laboratory equipment and financial support.

Edited by: S. Maak

Reviewed by: R. Pöhland and one anonymous referee

\section{References}

Camous, S., Kopecny, V., and Flechon, J. E.: Autoradiographic detection of the earliest stage of $[3 \mathrm{H}]$-uridine incorporation into the cow embryo, Biol. Cell., 58, 195-200, 1986.

Canettieri, G., Di Marcotullio, L., Greco, A., Coni, S., Antonucci, L., Infante, P., Pietrosanti, L., De Smaele, E., Ferretti, E., Miele, E., Pelloni, M., De Simone, G., Pedone, E. M., Gallinari, P., Giorgi, A., Steinkuhler, C., Vitagliano, L., Pedone, C., Schinina, M. E., Screpanti, I., and Gulino, A.: Histone deacetylase and Cullin3-RENKCTD11 ubiquitin ligase interplay regulates Hedgehog signalling through Gli acetylation, Nat. Cell Biol. , 12, 132-191, 2010.

Crozet, N., Huneau, D., Desmedt, V., Theron, M. C., Szollosi, D., Torres, S., and Sevellec, C.: In vitro fertilization with normal development in the sheep, Gamete. Res., 16, 159-170, 1987.

Driancourt, M. A. and Thuel, B.: Control of oocyte growth and maturation by follicular cells and molecules present in follicular fluid, Reprod. Nutr. Dev. rev., 38, 345-362, 1998.

Elia, D., Madhala, D., Ardon, E., Reshef, R., and Halevy, O.: Sonic hedgehog promotes proliferation and differentiation of adult muscle cells: involvement of MAPK/ERK and PI3K/Akt pathway, Biochim. Biophy. Acta., 1773, 1438-1446, 2007.

Hooper, J. E. and Scott, M. P.: Communicating with Hedgehogs, Nat. Rev. Mol. Cell. Biol., 6, 306-317, 2005.

Ikeda, S., Ichihara-Tanaka, K., Azuma, T., Muramatsu, T., and Yamada, M.: Effects of midkine during in vitro maturation of 
bovine oocytes on subsequent developmental competence, Biol. Reprod., 63, 1067-1074, 2000.

Ingham, P. W. and McMahon, A. P.: Hedgehog signaling in animal development: paradigms and principles, Genes. Dev., 15, 30593087, 2001.

Lee, K., Jeong, J., Kwak, I., Yu, C. T., Lanske, B., Soegiarto, D. W., Toftgard, R., Tsai, M. J., Tsai, S., Lydon, J. P., and DeMayo, F. J.: Indian hedgehog is a major mediator of progesterone signaling in the mouse uterus, Nat. Genet., 38, 1204-1219, 2006.

Lee, S. J., Lindsey, S., Graves, B., Yoo, S., and Olson, J. M.: Sonic Hedgehog-induced histone deacetylase activation is required for cerebellar granule precursor hyperplasia in medulloblastoma, Plos One. 8, 714-728, 2013.

Livak, K. J. and Schmittgen, T. D.: Analysis of relative gene expression data using real-time quantitative PCR and the 2(-Delta Delta C (T)) method, Methods, 25, 402-408, 2001.

Matsumoto, H., Zhao, X., Das, S. K., Hogan, B. L., and Dey, S. K.: Indian hedgehog as a progesterone-responsive factor mediating epithelial- mesenchymal interactions in the mouse uterus, Dev. Biol., 245, 280-290, 2002.

McGraw, S., Robert, C., Massicotte, L., and Sirard, M. A.: Quantification of histone acetyltransferase and histone deacetylase transcripts during early bovine embryo development, Biol. Reprod., 68, 383-389, 2003.

Mehnert, J. M. and Kelly W. K.: Histone deacetylase inhibitors: biology and mechanism of action, Cancer J., 13, 23-29, 2007.

Nguyen, N. T., Lin, D. P. C., Yen, S. Y., Tseng, J. K., Chuang, J. F., Chen, B. Y., Lin, T. A., Chang, H. H., and Ju, J. C.: Sonic hedgehog promotes porcine oocyte maturation and early embryo development, Reprod. Fertil. Dev., 21, 805-815, 2009.

Nguyen, N. T., Lin, D. P. C., Siriboon, C., Lo, N. W., and Ju, J. C.: Sonic hedgehog improves in vitro development of porcine parthenotes and handmade cloned embryos, Sci. Direct. Therio., 74, 1149-1160, 2010.

Nguyen, N. T., Lo, N. W., Chuang, S. P., Jian, Y. L., and Ju, J. C.: Sonic hedgehog supplementation of oocyte and embryo culture media enhances development of IVF porcine embryos, Reproduction, 142, 87-97, 2011.

Pangas, S. A.: Growth factors in ovarian development, Semin. Reprod . Med., 25, 225-34, 2007.

Ren, Y., Cowan, R. G., Harman, R. M., and Quirk, S. M.: Dominant activation of hedgehog signaling pathway in the ovary alters theca development and prevents ovulation, Mol. Endocrinol., 23, 711-723, 2009.
Ruiz i Altaba, A., Sánchez, P., and Dahmane, N.: Gli and hedgehog in cancer: tumours, embryos and stem cells, Nat. Rev. Cancer., 2, 361-372, 2002.

Russell, M. C., Cowan, R. G., Harman R. M., Walker, A. L., and Quirk, S. M.: The hedgehog signaling pathway in the mouse ovary, Biol. Reprod., 77, 226-236, 2007.

Spicer, L. J., Sudo, S., Aad, P. Y., Wang, L. S., Chun, S. Y., BenShlomo, I., Klein, C., and Hsueh, A. J. W.: The hedgehogpatched signaling pathway and function In the mammalian ovary: a novel role for hedgehog proteins in Stimulating proliferation and steroidogenesis of theca cells, Reproduction, 138, 329-339, 2009.

Stebbins-Boaz, B., Hake, L. E., and Richter, J. D.: CPEB controls the cytoplasmic polyadenylation of cyclin, Cdk2 and c-mos mRNAs and is necessary for oocyte maturation in Xenopus, Embo. J., 15, 2582-2592, 1996.

Takamato, N., Zhao, B. H., Tsai, S. Y., and Demayo, F. J.: Identification of Indian hedgehog as a progesterone-responsive gene in the murine uterus, Mol. Endocrinol., 16, 2338-2348, 2002.

Tervit, H. R., Whittingham, D. G., and Rowson, L. E. A.: Successful culture of sheep and cattle ova, J. Reprod. Fertil., 30, 493-497, 1972.

Thompson, J. G., Gardner, D. K., Pugh, P. A., McMillan, W. H., and Tervit, H. R.: Lamb birth weight is affected by culture system utilized during in vitro pre-elongation development of ovine embryos, Biol. Reprod., 53, 1385-1391, 1995.

Wijgerde, M., Ooms, M., Hoogerbrugge, J. W., and Grootegoed, J. A.: Hedgehog signaling in mouse ovary: Indian hedgehog and desert hedgehog from granulosa cells induce target gene expression in developing theca cells, Endocrinology, 146, 3558-3566, 2005.

Wu, X., Ding, S., Ding, Q., Gray, N. S., and Schultz, P. G.: A small molecule with osteogenesis-inducing activity in multipotent mesenchymal progenitor cells, J. Am. Chem. Soc., 124, 14520-14521, 2002.

Zuccotti, M., Boiani, M., Ponce, R., Guizzardi, S., Scandroglio, R., and Garagna, S.: Mouse Xist expression begins at zygotic genome activation and is timed by a zygotic clock, Mol. Reprod. Dev., 61, 14-20, 2002. 